\title{
レーザー解説
}

光励起メチルアルコールレーザーの発振機構

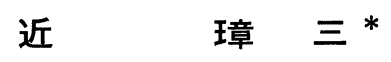

(1985年11月25日受理)

\section{Oscillation Mechanism of Optically Pumped Methyl Alcohol Laser}

Shozo $\mathrm{KON}^{*}$

(Received November 25, 1985)

\section{1. はじめに}

遠赤外レーザーは $\mathrm{Ne}, \mathrm{HCN}$ 等の放電励起 に はじまり，しばらくは新しい物質の探究に努力 がはらわれた。1970年に光励起分子レーザーが 成功して以来, その研究に大きなはずみが加わ つた。以後新物質, 新発振ラインが次々とみつ かる中で, メ夕ノール $\left(\mathrm{CH}_{3} \mathrm{OH}\right)$ は発振 ライ ンの多いこと, 発振波長域の広いことで, 特異 な物質であった。Chang によって発振が報告 された当時は，接近した波長のペアがいくつか 存在していて, その様子は奇異にさえ思えた。 しかしそのエネルギー遷移の構造が明らかにな ると, 彼等の測定した波長はきわめて正確で, 警くべきものがある。このようなメタノールの 発振ラインの多様さは分子全体の回転エネルギ 一に加えて, $\mathrm{O}-\mathrm{H}$ 基の $\mathrm{CH}_{3}$ 基に対する束縛回 転 (hindered rotation) があって, 複雑な工 ネルギー構造を有するからである ${ }^{1} 。$ 更にO H結合のねじれ振動 (torsional vibration) が レーザ一の場合あらわれて, 複雑さを増してい る。 $\mathrm{CO}_{2} レ$ ザーの発振周波数はメタノールの
$\mathrm{C}$ - $\mathrm{O}$ 伸縮振動による吸収バンドと重なって, 多くのラインが強い吸収をうける。そのために メタノールの振動励起状態での回転エネルギー 準位間に反転分布がおこる。光励起メタノール の成功以来, 毎年のように新しい発振線が発見 されて，1982年にそれをまとめたものが出版さ れた ${ }^{2-7)}$ 。その発振線の数は $\mathrm{CH}_{3} \mathrm{OH}$ におて 400 本以上に達し ${ }^{2)}$, その同位体も含めると 950 本にもなる ${ }^{4,5)}$ 。これらの励起光源は通常の ${ }^{12} \mathrm{C}$ ${ }^{16} \mathrm{O}_{2}$ の C W 発振であるが, TEA, 導波管レーザ 一, sequence band 等も一部に含まれる。 $\mathrm{CO}_{2}$ のアイソトープとして, ${ }^{12} \mathrm{C}^{18} \mathrm{O}_{2},{ }^{13} \mathrm{C}^{16} \mathrm{O}_{2},{ }^{13} \mathrm{C}$ ${ }^{18} \mathrm{O}_{2}$ 等も励起光源に使われる。

メタノール中の水素が重水素に置換された重 水素メ夕ノ一ルも, その吸収バンドが $\mathrm{CO}_{2} レ$ ザーに重なるので発振線の数はさらにふえる ${ }^{4,5,7}$ 。 $\mathrm{CH}_{3} \mathrm{OD}:$ 63本, $\mathrm{CH}_{2} \mathrm{DOH}: 68$ 本, $\mathrm{CHD}_{2} \mathrm{OH}$ : 11本, $\mathrm{CD}_{3} \mathrm{OH}: 122$ 本, ${ }^{*} \mathrm{CD}_{3} \mathrm{OD}: 139$ 本に 達する。これらの発振ラインの一部は周波数精 密測定によって 8 林までの精度でその值が求ま るようになり, 解析はいちぢるしく進んだ。従 来の回折格子やフーリ土分光による測定では,

* 名古屋大学工学部応用物理学教室 (464 名古屋市千種区不老町)

* Department of Applied Physics, Faculty of Engineering, Nagoya University (Furocho Chikusa-ku, Nagoya 464)

**この中には不純物 $\mathrm{CD}_{2} \mathrm{O}$ によるものもあるといわれる。 
その分解はせいぜい $1 \mathrm{GHz}$ 程度であって, $\mathrm{CH}_{3}$ $\mathrm{OH}$ のドップラー幅の数 $\mathrm{MHz}$ までの分解は 到 底不可能であった。しかしレーザーの周波数測 定は $0.1 \mathrm{MHz}$ までの值が求まるようになり，ド ップラー幅の限界をこえた解析が可能となった。 メタノールレーザーの最初の発振におくれるこ と 7 年にして, Henningsen 等により最初のア サイメントが試みられ, 以後の解析により $\mathrm{CH}_{3} \mathrm{OH}$ で 136本.のラインのアサインメントが 行われた。ここではメタノールの振動・回転工 ネルギーの構造をのべて, その励起過程, 発振 の遷移則, アサインメントの方法, ライン間の 相互作用等について説明する。

\section{2. 光励起と発振の機構}

2.1 ポンピング用 $\mathrm{CO}_{2}$ レーザー

$\mathrm{CO}_{2}$ レーザーはメタノールとその同位体の吸 収バンドが一部の波長で一致するので良いポン ピング光源として使われる。その吸収バンドの 範囲と $\mathrm{CO}_{2}$ レーザーの発振範囲を Fig. 1 に示 す。メタノールのCO 伸縮振動は $\mathrm{CH}_{3} \mathrm{OH}$ で $1034, \mathrm{CH}_{3} \mathrm{OD}$ で1041, $\mathrm{CD}_{3} \mathrm{OH}$ で985, $\mathrm{CD}_{3} \mathrm{OD}$

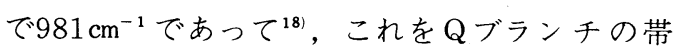
頭として約 $\pm 50 \mathrm{~cm}^{-1}$ 以上の範囲で吸収を示す。 一方 $\mathrm{CO}_{2}$ レーザーはFig. 1 に示す 4 種類の同 位体が励起光源として使われる ${ }^{8,10,111}$ 。これらの 同位体を使うと発振の空間域を良くカバーして いることがわかる。また sequence バンドによ る励起 ${ }^{2,14)} も \mathrm{CO}_{2}$ レーザーの規則的な回転レベ ル間を補間するので，いずれも励起光源として すぐれている。そのほかに ${ }^{12} \mathrm{C}^{16} \mathrm{O}^{18} \mathrm{O},{ }^{14} \mathrm{C}^{16} \mathrm{O}_{2}$, ${ }^{14} \mathrm{C}^{18} \mathrm{O}_{2}$ 等の発振もあり ${ }^{7)},{ }^{13} \mathrm{CH}_{3} \mathrm{OH}$ 発振や ${ }^{12,13}$, ${ }^{13} \mathrm{CD}_{3} \mathrm{OH}$ 発振9) もあるので, これら励起光と発 振物質の組み合わせによって大きな発展が期待 できる。そのほかに, TEA $\mathrm{CO}_{2}$ レーザーで励 起したものがあり, Feld 等は ${ }^{15,16)} 15$ 気圧までの 放電で $2 \mathrm{GHz}$ の帯域幅で多くのラインを発振 させた。しかしポンピング光や発振光の周波数 が不確かとなってアサイメントには必ずしも適 さなかった。
2.2 赤外・遠赤外吸収スペクトル

メタノール $\left(\mathrm{CH}_{3} \mathrm{OH}\right)$ の吸収スペクトルに ついては, 古くから多くの人達によって調べら れた。波数 $50 \mathrm{~cm}^{-1}$ 以下の遠赤外領域では対称コ マ分子に似た回転スペクトルが (Jの変化によ る）規則正しくあらわれる ${ }^{17)}$ 。それ以上の波数 となると $\mathrm{O}-\mathrm{H}$ 結合の内部回転(internal rotation）によるスペクトルがあらわれだし，それ が通常の回転スペクトルと結合して非常に複雑 となる ${ }^{18,19,28)}$ 。これらの吸収は $900 \mathrm{~cm}^{-1}$ 近くまで 続き,このことがメタノールが短波長まで発振 することのできる原因となっている。約 970 ～ $1080 \mathrm{~cm}^{-1}$ にわたってCO 伸縮振動と全体の回転 との結合による吸収バンドがあらわれる。これ をFig. 2 に示す。このバンドは $\mathrm{CO}_{2}$ レーザー の周波数と重なり，メタノールをよく励起する ことができる。半導体レーザーの出現によって これらの吸収は $100 \mathrm{MHz}$ 程度の微細構造まで分 析することが可能となり ${ }^{38,115,116)}$, 光音響分光法 を用いれば $\mathrm{MHz}$ オーダーの分解も可能となる。 これらの結果はメタノールレーザーの解析に非 常に有効な手段を与えた。

2. $3 \times$ タノールのエネルギー準位

メタノールは対称コマ分子から僅かにずれた 非対称コマ分子であって，その分子構造をFig. 3 に示す。 $\mathrm{O}$ に結合された $\mathrm{H}$ 原子は $\mathrm{CH}_{3}$ 基の回 転対称軸のまわりに回転できて, $\mathrm{CH}_{3}$ 基による
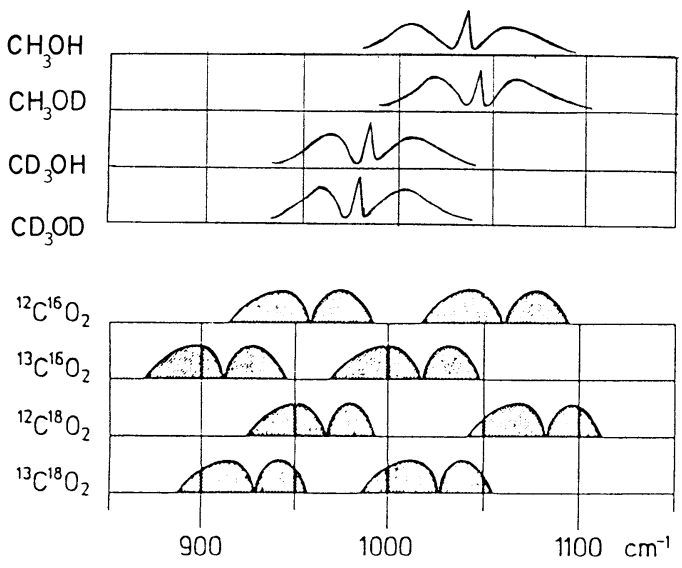

Fig. 1 Spectral coincidence with $\mathrm{CO}_{2}$ lasers and methanol absorption ${ }^{1}$. 

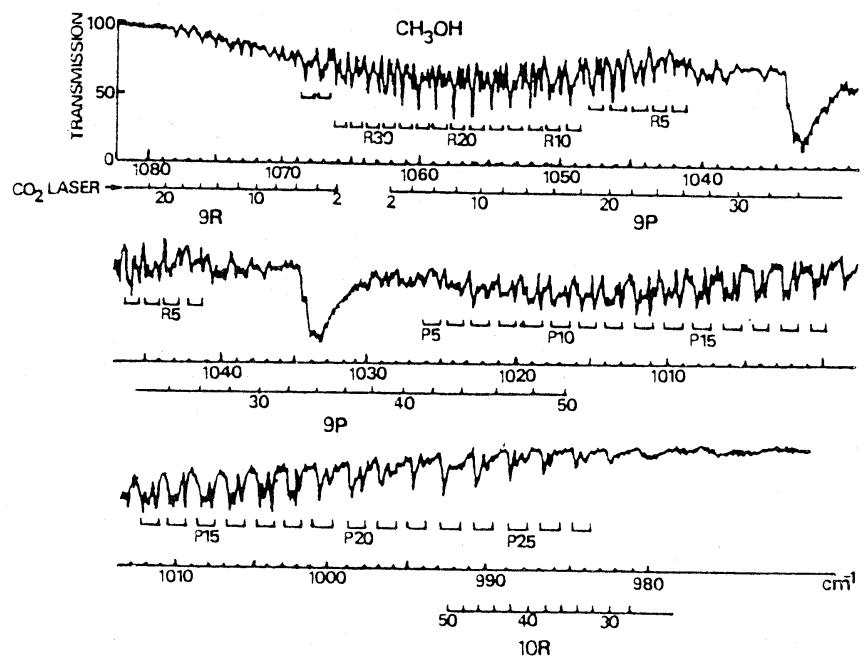

Fig. 2 Superimposed C-O strech of $\mathrm{CH}_{3} \mathrm{OH}$ and and ${ }^{12} \mathrm{C}^{16} \mathrm{O}_{2}$ laser spectra.

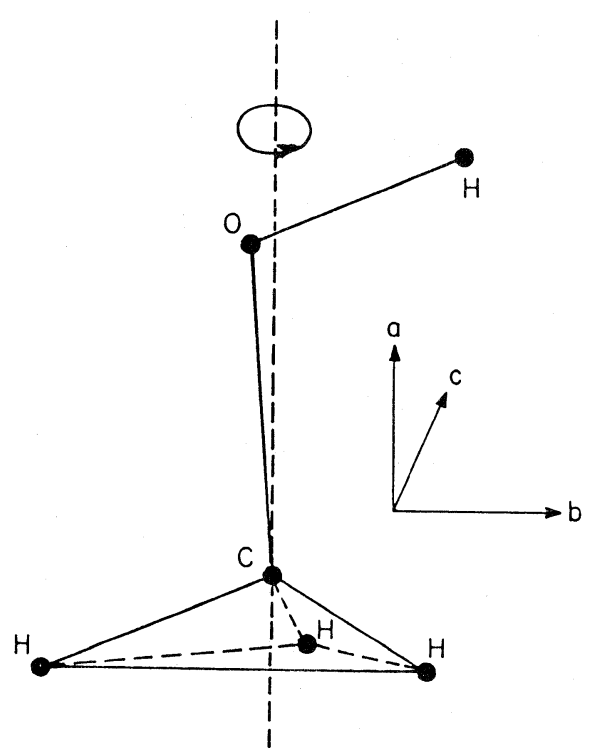

Fig. $3 \mathrm{CH}_{3} \mathrm{OH}$ structure ${ }^{113}$.

3 回対称ポテンシャルの中で束縛内部回転とね じれ振動のエネルギーを指つ。従つて通常の全 角運動量の回転量子数 $J$ とその分子軸成分 $K$ の ほかにねじれ振動量子数 $n$ と内部回転状態を あらわす $\tau(=1,2,3)$ が導入される。こ れらによって全回転エネルギ一準位は $(n, \tau, K)$

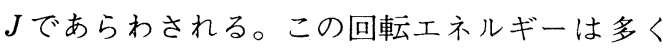
の研究者によって調べられ，40年以上にわたっ て改良につぐ改良が加えられた ${ }^{18-39)}$ 。
$\mathrm{CO}_{2}$ レーザーで励起されたメタノールのエネ ルギー状態は次の各エネルギーの和となる。CO 伸縮振動励起エネルギー $E_{\mathrm{co}}$, 対称コマ分子に 近似な回転エネルギー $E_{\mathrm{J}, \mathrm{k}}$, 内部回転エネルギ 一 $E_{\mathrm{T}}$, 非対称性から生じるエネルギー $E_{\mathrm{asym}}$ で ある。

$$
E_{\mathrm{n} \tau \mathrm{K}}^{\mathrm{v}}=E_{\mathrm{Co}}+E_{\mathrm{JK}}+E_{\mathrm{T}}+E_{\mathrm{asYm}}
$$

$E_{\mathrm{JK}}$ は $J(J+1)$ と $K^{2}$ とそれらの遠心力歪による 項を含んだものであって対称コマ分子として扱 つたものと同じである ${ }^{40)} 。 E_{\mathrm{T}}$ は内部回転による

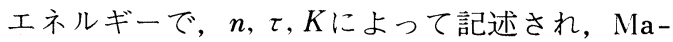
thieu 方程式を解くことによってえられる。そ の結果は内部回転のポテンシャルエネルギーと 運動エネルギーを含み, さらにそれらの遠心力 歪やポテンシャルの歪による補正項をもつ。さ らにJに依存しない経験的 Kirtman の補正係 数が 7 個まで導入されている ${ }^{29,41)}$ 。これらの值 をすべてあらわすと21個の項からなり複雑な計 算となる ${ }^{33,39)}$ 。これらの係数は多くの人によっ て求められてきたが, $J(J+1)$ の幕級数の和と してまとめることができる ${ }^{1,6)}$ 。

$$
\begin{aligned}
E_{\mathrm{n} \tau \mathrm{KJ}}^{\mathrm{v}}= & E_{\mathrm{Co}}+E_{\mathrm{T}}^{\mathrm{v}}(n \tau K)+B^{\mathrm{v}}(n \tau K) J(J+1) \\
& -D^{\mathrm{v}}(n \tau K) J^{2}(J+1)^{2} \cdots \cdots \cdots \cdots \\
& +\quad \text { asymmetry splitting })\left(\mathrm{cm}^{-1}\right)
\end{aligned}
$$


ここで添字 $v$ は $\mathrm{CO}$ 振動の励起状態での係数を あらわしているが, この状態での值について求

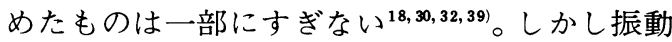
励起レベルでの係数は基底レベルでの係数のう ちの一部を補正することによって求められる ${ }^{1,6)}$ 。 また $\mathrm{CH}_{3} \mathrm{OH}$ については(2)式の 4 乗の項までの 係数を 8 桁以上まで求められた ${ }^{42,43)}$ 。いずれに してもこれらの值は励起光と発振光の周波数精 密測定によってはじめて求めることができた。 内部回転のエネルギーだけをとると， $\tau=1 ，$ 2,3 ，に対応した $K$ の関数として描け，同種 の周期関数となる ${ }^{18,23)}$ 。点群 $\mathrm{C}_{3}$ の同一対称種の 間でのみ遷移可能なことをあらわすのに便利な ように, $A, E_{1}, E_{2}$ で内部回転状態をあらわす

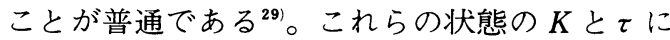
対応する表示を次のように決める。

$$
\begin{aligned}
& A \rightarrow K+\tau=3 N+1 \\
& E_{1} \rightarrow K+\tau=3 N \\
& E_{2} \rightarrow K+\tau=3 N-1
\end{aligned}
$$

非対称項 Easym は $\pm K$ に対応して分裂するが, 3 回対称の場合 $E_{1}(-K)$ と $E_{2}(+K)$ および $E_{1}$ $(+K)$ と $E_{2}(-K)$ は同一值となり, 縮退してい る。 $A$ 状態だけ分離して，その值は $A^{+}, A^{-}$と 表示される。この分離は $K$ に依存して变化して $K$ が大きい所では殆ど無視できる ${ }^{25}$ 。

\section{3. 遷移の法則}

メタノールレーザー光の吸収と発振に関する 種々の法則が理論的に求められている。この法 則に従ってレーザー光が放射されるから，解析 に必要な重要な事項を以下に説明する。

\section{1 選択則}

メタノール分子の励起は分子軸方向の $\mathrm{CO}$ 伸 縮振動によって行われるので，分子軸に垂直方 向の量子数変化はない。従って励起に対する選 択則は

$$
\begin{aligned}
& \Delta V=1, \Delta J=0, \pm 1, \\
& \Delta K=\Delta n=\Delta \tau=0
\end{aligned}
$$

$\Delta J=-1,0,1$ に対応して吸収は $\mathrm{P}, \mathrm{Q}, \mathrm{R}$ ブラ ンチとなる。発振のさいの回転遷移則は永久 双極子モーメントの变化が軸方向に平行か垂直 かによって，a-type とb-typeとになる。a-type に対しては $K$ の変化がないから選択則は

$$
\Delta K=0, \Delta J= \pm 1, \Delta \tau=0, \Delta n=0
$$

b-type の選択則は

$$
\begin{array}{rlr}
\Delta K=+1, & \Delta J=0, \pm 1, \\
& \tau: 1 \rightarrow 3,3 \rightarrow 2,2 \rightarrow 1, \Delta n: \text { arbit. } \\
\Delta K=-1, & \Delta J=0, \pm 1, \\
& \tau: 1 \rightarrow 2,2 \rightarrow 3,3 \rightarrow 1, \Delta n: \text { arbit. }
\end{array}
$$

$A$ 状態に対しでに，土の二重項の遷移に対して， 次の選択則が加わる。

$$
\begin{aligned}
& \pm \leftrightarrow \pm \begin{cases}\Delta n: \text { even, } & \Delta J= \pm 1 \\
\Delta n: \text { odd }, & \Delta J=0\end{cases} \\
& \pm \leftrightarrow \mp \begin{cases}\Delta n: \text { even, } & \Delta J=0 \\
\Delta n: \text { odd }, & \Delta J= \pm 1\end{cases}
\end{aligned}
$$

励起によって発振するレーザーの利得は回転の 遷移双極子モーメントと内部回転の双極子モー メントの積となり ${ }^{23}$, 発振のおこりやすい遷移 が予測できる。Fig. 4 にそのレベルを示す。図 でねじれ振動レベルの変化のないとき $(\mathbf{a})$ と変 化するとき(b)を示し， c, b , a の順で発振が強 い。点線の遷移は非常におこりにくい。

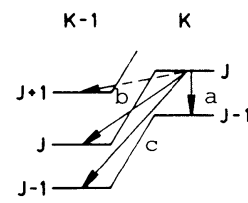

(a)

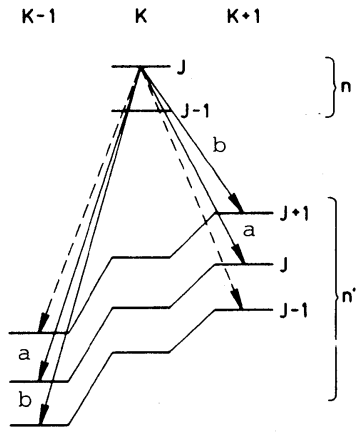

(b)

Fig. 4 Dominat emission lines within (a) the same torsional state (b) different torsional states ${ }^{1)}$. 


\section{2 偏光}

励起 $\mathrm{CO}_{2}$ レーザーが直線偏光だと, 遠赤外発 振光は励起光の偏光方向に平行か垂直の直線偏 光となる ${ }^{44,45)}$ 。その間の法則は次のように説明 できる。Q $\mathrm{Q}$ 励起のとき，即ち $\Delta J=0$ のときは 励起光の偏光方向が双極子の回転面に垂直な分 子と作用する。即ち角運動量ベクトルと励起光 の電場の方向は一致する。これに対して $\mathrm{P}, \mathrm{R}$ 励起の場合， $\Delta J= \pm 1$ だから励起光の偏光方 向が双極子の回転面と同方向にある分子が励起 される。発振光の $J$ の変化に対しても全く同様 な関係となるから，このことをまとめてFig. 5 に示す。その結果を式であらわすと

$$
\begin{aligned}
& \Delta J_{\mathrm{P}}+\Delta J_{\mathrm{e}}= \text { even } \rightarrow \text { parallel } \quad(\|) \\
& \text { odd } \rightarrow \text { orthogonal }(\perp)
\end{aligned}
$$

このことは一般には，遷移双極子モーメントの 行列要素を考慮することによって説明できる ${ }^{46)}$ 。

\section{3 発振線の結合則}

第 4 図 (a) に示したような 3 本の発振線の間 には結合則（combination relation）が存在す る。図で $\mathrm{a}, \mathrm{b}, \mathrm{c}$ の遷移に対する周波数（又は波 数）を $\nu_{\mathrm{a}}, \nu_{b}, \nu_{\mathrm{c}}$ とするとその間に

$$
\nu_{\mathrm{c}} \simeq \nu_{\mathrm{a}}+\nu_{\mathrm{b}}
$$

の関係がある。この関係は発振線のアサインメ ントに非常に有用である。実例をFig. 6 に示す。 図は $9 \mathrm{R}(14) ， 9 \mathrm{R}(19) ， 9 \mathrm{P}(36)$ 励起光の場合で, 工 ネルギーレベルの上に $(n \tau k)$ の值を, 横に $J$ 值 を記す。前 2 者は $\mathrm{R}$ ブランチ吸収で，最後は $\mathrm{Q}$ ブランチ吸収による励起である。 $\mathrm{a}^{\prime} \mathrm{bc}$ の間に結 合則が成り立ち， $\mathrm{a}^{\prime}$ 一 $\mathrm{a}$ の值が小さいことから エネルギーを推量できる。 あわせて $\Delta J=-1$ の場合の $\mathrm{a}$ と $\mathrm{c}$ の偏光が同じことも確認してお $<。$

\section{4 発振線間の相互作用}

第 4 図のように上のエネルギー準位が同一で あるときにはライン間に競合 (competition)

\begin{tabular}{|c|c|c|c|c|c|c|}
\hline $\begin{array}{l}\text { pump } \\
\text { field }\end{array}$ & $\begin{array}{l}\text { ground } \\
\text { state }\end{array}$ & $\begin{array}{l}\text { pump } \\
\text { line }\end{array}$ & $\begin{array}{l}\text { excited } \\
\text { state }\end{array}$ & $\begin{array}{c}\text { emission } \\
\text { line }\end{array}$ & $\begin{array}{c}\text { gain } \\
\text { polarization }\end{array}$ & $\begin{array}{c}\text { relative } \\
\text { polarization }\end{array}$ \\
\hline \multirow{8}{*}{$\vec{E}_{\text {pump }}$} & \multirow{8}{*}{$\Theta$} & \multirow{4}{*}{$\begin{array}{c}Q \\
\Delta J_{P}=0\end{array}$} & \multirow{4}{*}{ 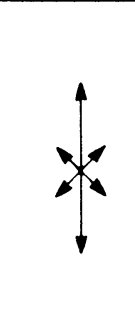 } & $Q$ & strong & \multirow{2}{*}{11} \\
\hline & & & & $\Delta \mathrm{J}_{e}=0$ & $\rightarrow$ weak & \\
\hline & & & & \multirow{2}{*}{$\begin{array}{c}P, R \\
\Delta J_{e}= \pm 1\end{array}$} & $\uparrow$ weak & \multirow{2}{*}{1} \\
\hline & & & & & $\longrightarrow$ strong & \\
\hline & & \multirow{4}{*}{$\begin{array}{c}P, R \\
\Delta J_{P}=\mp 1\end{array}$} & \multirow{4}{*}{+1} & \multirow{2}{*}{$\begin{array}{c}Q \\
\Delta J_{e}=0\end{array}$} & $\uparrow$ weak & \multirow{2}{*}{$\perp$} \\
\hline & & & & & $\longrightarrow$ strong & \\
\hline & & & & \multirow{2}{*}{$\begin{array}{c}P, R \\
\Delta\rfloor_{e}= \pm 1\end{array}$} & strong & \multirow{2}{*}{11} \\
\hline & & & & & $\rightarrow$ weak & \\
\hline
\end{tabular}
がおこり，あるラインの発振がおさえられる。 この競合は遠赤外レーザーの同調曲線上で変調

Fig. 5 Palarization directions in ground state and excited state ${ }^{11}$. 


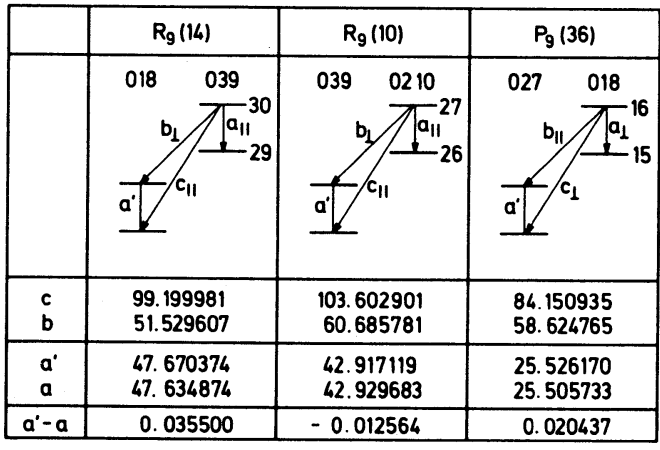

Fig. 6 Combination relations between emission lines in $\mathrm{n}=0$ state (units of $\left.\mathrm{cm}^{-1}\right)^{1}$.

された形となってあらわれるが47)，共振器の縦 ・横モード間が等間隔となるように設計すると 明瞭となる ${ }^{48)}$ 。Fig. 7(a)に9P (34) 励起による $699.4 \mu \mathrm{m}$ の同調曲線を示す。図で弱くなった ピークは70.5 $\mu \mathrm{m}$ の同時発振により抑えられて いる。また下のレベルから次のレベルへとカス ケード発振するときは同時発振のときだけ強い ピークを生じる。Fig. 7(b)は $185.5 \mu \mathrm{m}$ が 70.5 $\mu \mathrm{m}$ のカスケード発振であることを示し，ほか に253.5 $\mu \mathrm{m}$ と $264.5 \mu \mathrm{m}$ もカスケード発振であ ることがわかった。このことはこの励起光によ

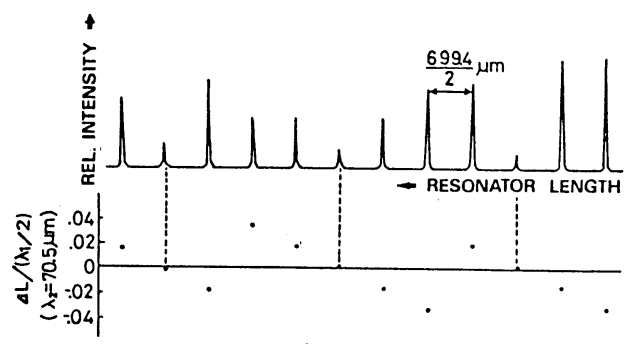

(a)

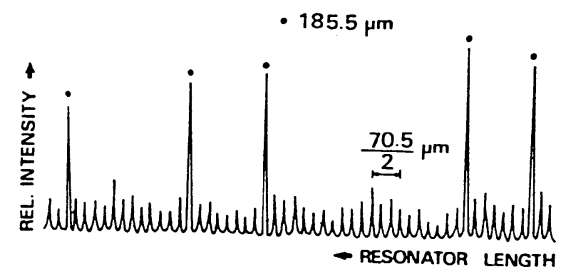

(b)

Fig. 7 Tuning curves of FIR emissions (a) competitive line (b) cascade transition line.
る発振のアサインメントの確証になった。

\section{4.メタノールレーザーの発振と解析}

4. 1 ×タノールの発振

1970年 Chang によって最初の光励起メ夕ノ ールが発振して以来毎年のように新しい発振線 が見出だされ，1984年現在406本の発振線 が 報 告された $8,10,11,44-73)$ 。励起光源は殆ど $\mathrm{CW} \mathrm{CO}_{2}$ レ ーザーであるが，この中にはwaveguide，TEA， sequence バンド2,14)，同位体 $\mathrm{CO}_{2}$ レーザーによ るものが10,11) 180 本近く含まれる。この発振線 の数をTable Iに示す。

メタノールの同位体についても ${ }^{13} \mathrm{CH}_{3} \mathrm{OH}$, $\mathrm{CH}_{3} \mathrm{OD}, \mathrm{CD}_{3} \mathrm{OH}, \mathrm{CD}_{3} \mathrm{OD}$ 等が発振する この発振の特徵をあげれば，1）メタノールは 発振線数が多いだけでなく，その波長域も 27.7 $\mu \mathrm{m}\left(\mathrm{CD}_{3} \mathrm{OH}\right)^{94)}$ から最大 $2923.0 \mu \mathrm{m}\left(\mathrm{CD}_{3} \mathrm{OD}\right)^{95)}$ までと，もっとも広い。特に $80 \mu \mathrm{m}$ 以下で多く の発振ラインをもつ物質は $\mathrm{NH}_{3}$ と $\mathrm{D}_{2} \mathrm{O}$ を除け ば,メタノールは唯一の物質である。2）強度

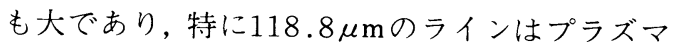
診断等に多くの応用がある。その上, $\mathrm{CD}_{3} \mathrm{OD}$ の $184.8 \mu \mathrm{m}^{78 !}$ や $^{13} \mathrm{CD}_{3} \mathrm{OH}$ の $127.0 \mu \mathrm{m}$ の強度は

Table I Number of FIR laser lines from methyl alcohol.

\begin{tabular}{|c|c|c|c|c|}
\hline methanol & ${ }^{12} \mathrm{C}^{16} \mathrm{O}_{2}^{2}$ & ${ }^{13} \mathrm{C}^{16} \mathrm{O}_{2}$ & ${ }^{12,13} \mathrm{C}^{18} \mathrm{O}_{2}$ & $\begin{array}{c}\text { assigned } \\
\text { line }\end{array}$ \\
\hline $\begin{array}{c}\mathrm{CH}_{3} \mathrm{OH} \\
\left({ }^{13} \mathrm{CH}_{3} \mathrm{OH}\right)\end{array}$ & $\begin{array}{c}328 \\
(67)\end{array}$ & 23 & 55 & $\begin{array}{c}136 \\
(20)\end{array}$ \\
\hline $\mathrm{CH}_{3} \mathrm{OD}$ & 68 & & & 15 \\
\hline $\begin{array}{c}\mathrm{CH}_{2} \mathrm{DOH}, \\
\mathrm{CHD}_{2} \mathrm{OH}\end{array}$ & 79 & & & 0 \\
\hline $\begin{array}{c}\mathrm{CD}_{3} \mathrm{OH} \\
\left({ }^{13} \mathrm{CD}_{3} \mathrm{OH}\right)\end{array}$ & $\begin{array}{c}152 \\
(35)\end{array}$ & 5 & & 7 \\
\hline $\begin{array}{c}\mathrm{CD}_{3} \mathrm{OD} \\
\left({ }^{13} \mathrm{CD}_{3} \mathrm{OD}\right)\end{array}$ & $\begin{array}{c}134 \\
(13)\end{array}$ & 5 & & 3 \\
\hline
\end{tabular}

$\begin{array}{cll}\mathrm{CH}_{3} \mathrm{OH} & \text { waveguide } & 58 \\ & \text { T E A } & 56 \\ & \text { sequence } & 21 \\ { }^{13} \mathrm{CH}_{3} \mathrm{OH} & \text { waveguide } & 27\end{array}$


$118.8 \mu \mathrm{m}$ を浚駕するといわれる。3) シュタル ク効果によって吸収と発振波長を同調できる。 従ってレーザー光の変調も容易に行える。

メタノールレーザーの解析に大きな役割をは たしたものはビート周波数による周波数の精密 測定であろう。NBSのEvenson 等は $\mathrm{CH}_{3} \mathrm{OH}$ で83本のラインの精密測定を行い ${ }^{96,97)}$ ，それら の結果は光速の標準值測定に飛躍的な発展をも たらした ${ }^{981}$ そのほかの精密測定は $\mathrm{CH}_{3} \mathrm{OD}^{99)}$, $\mathrm{CD}_{3} \mathrm{OH}^{7)}, \mathrm{CD}_{3} \mathrm{OD}^{89)},{ }^{13} \mathrm{CH}_{3} \mathrm{OH}^{13)}$ 等について行 われている。

4. 2 メタノールレーザー線のアサインメント メタノールのアサインメントにあたってはま ず(2)式の回転エネルギー準位の計算を行わねば ならない。その計算は厄介であったが，計算方 法と係数はメタノールとその同位体について， 振動の基底レベルに対して与えられた ${ }^{33 !}$ 。内部 回転のエネルギーの值は $n=0 \sim 5, K=0 \sim 10$ までについて Sternによって表示化された ${ }^{36,37)}$, この值に全回転エネルギーを加えればエネルギ 一は容易に求まる。 CO 伸縮振動の励起状態 $(v=1)$ に対しては, いくつかの係数に若干の
補正を加えたものがHenningsen によって与え られている ${ }^{1)}$ 。彼は励起光の吸収に相当する遷 移を $\mathrm{P}, \mathrm{Q}, \mathrm{R}$ 各ブランチで $K=0 \sim 10, \quad J=0$ 〜35までの表を与えている ${ }^{1}{ }_{0} \quad n=0 \sim 2$ まで も含めた吸収ラインの波数を波数順にこまかく 与えた表も作成されている ${ }^{6}$ 。 この表から振動 励起状態のエネルギ一もチエックできる。メ夕 ノールの同位体については Woods の赤外吸収 スペクトルから一部推察できるが18), $\mathrm{CD}_{3} \mathrm{OD}$ については十分なデータはえられていない。

4. 2.1 結合則によるアサインメント

同一励起光で 3 本以上のラインが発振すると きはFig. 6 のように(9)式の結合則が成り立つか どうかをみる。 $\mathrm{b}$ ラインは $\mathrm{a}, \mathrm{c}$ と別な偏光面を もち， $\mathrm{a}<\mathrm{c}$ から $\mathrm{a}^{\prime}$ は容易に決定できる。

次に(2)式の係数 $B^{\mathrm{v}}$ の 2 倍の值で $\mathbf{a}^{\prime}$ を割つた

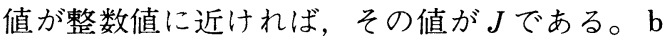
のラインは $J$ に依存しないので内部回転のエネ ルギー值から $K$ と $\tau$ が求まる。이잉

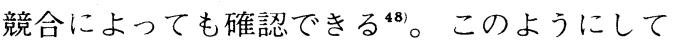
求めた発振ラインの代表例を $9 \mathrm{P}(36), 10 \mathrm{R}(38)$ 励 起光について Fig. 8 に示す。 $a, b, c 3$ 本のラ

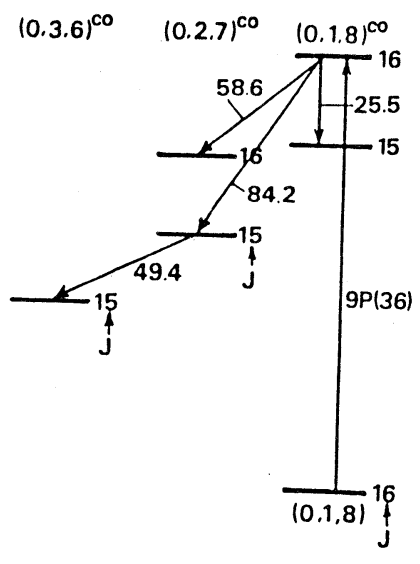

(a)

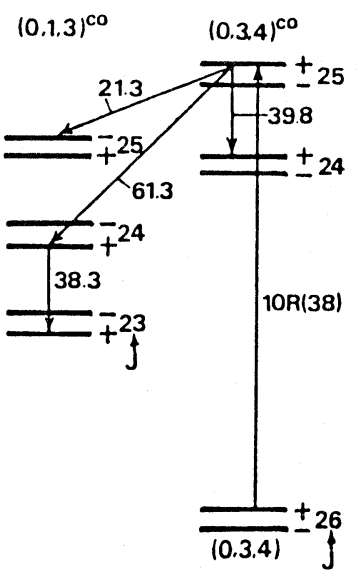

(b)

Fig. 8 Transition levels pumped by (a) $9 \mathrm{P}(36)$ line and (b) 10R38) line. Energy differences are indicated in units of $\mathrm{cm}^{-1}$. 
インのうち $\mathrm{a}$ は利得も低く発振しないことが多 い。そのときは逆に $(\mathrm{c}-\mathrm{b})$ より $\mathrm{a}^{\prime}$ を求めて, $\mathrm{a}$ を 実験で探索することもある。これらの計算値は $v=1$ の励起状態では若干異なるので十 分チ工 ックしなければならない。さらにマイクロ波と の二重共鳴吸収を測定したり ${ }^{104,109-112)}$, シュ夕 ルク効果によりラインの分裂の観測より $J, K$ を 確定することも行われる ${ }^{113,114)}$, 半導体レーザー による微細構造の解析も行われる ${ }^{115,116)}$ 。励起光 のチエックには内部回転のポテンシャル障壁の 值 $V_{3}$ が重要となる。 $\mathrm{CH}_{3} \mathrm{OH}$ でのCO 振動吸収 スペクトルが $1 \mathrm{~cm}^{-1}$ にわたって広がる原因は $V_{3}$

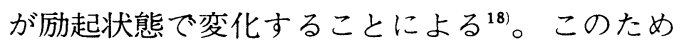

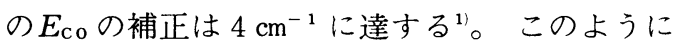
してアサインされたラインの数は136本である6。

\section{4. $2.29 \mathrm{P}(34)$ 問題}

1970年の Chang の報告で $9 \mathrm{P}(34)$ の単一励起 光で異常なほどの多数の発振線がみられた。そ の中で $1.4,1.6 \mathrm{~cm}^{-1}$ 分離したぺアのラインが 6 本あった。このようなラインは結合則に従う 三角形遷移では説明できない。はじめは $n=1$ $\rightarrow 0$ の遷移からの3 段力スケード発振とみられ

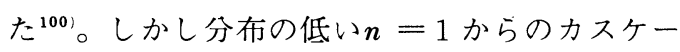
ドは考えにくく2段カスケードであるとの考え もあった ${ }^{16,117}$ 。後に周波数の精密測定と $9 \mathrm{P}(38)$ 励起光によるペアラインを組み合わせると帛, 励起光を含めた大きなエネルギーループ間に結 合則がみたされることがわかった。これらの状 態を Fig. 9 に示す。眓で（025）の励起レベル は大きく分裂しており，このレベルを混成(hybridized) レベルと名付けた。この分裂はAレ ベルの分裂では考えられない大きな分裂であっ て, $\mathrm{CH}_{3}$ のロッキングモードとの相互作用によ うておこる分裂であると考えられる。この新し いモードをX振動とあらわし,この振動と(016) レベルとの結合による仮想レベル $(016)^{\mathrm{x}}$ を導 導入した。即ち(016)レベルは $(016)^{\mathrm{co}}$ と $(016)^{\mathrm{x}}$ の 2 つレベルがあることになる。

このアサインメントはマイクロ波による二重 共鳴 ${ }^{104)}$ や7 $70.6 \mu \mathrm{m}$ からのカスケード発振 ${ }^{481}$ な

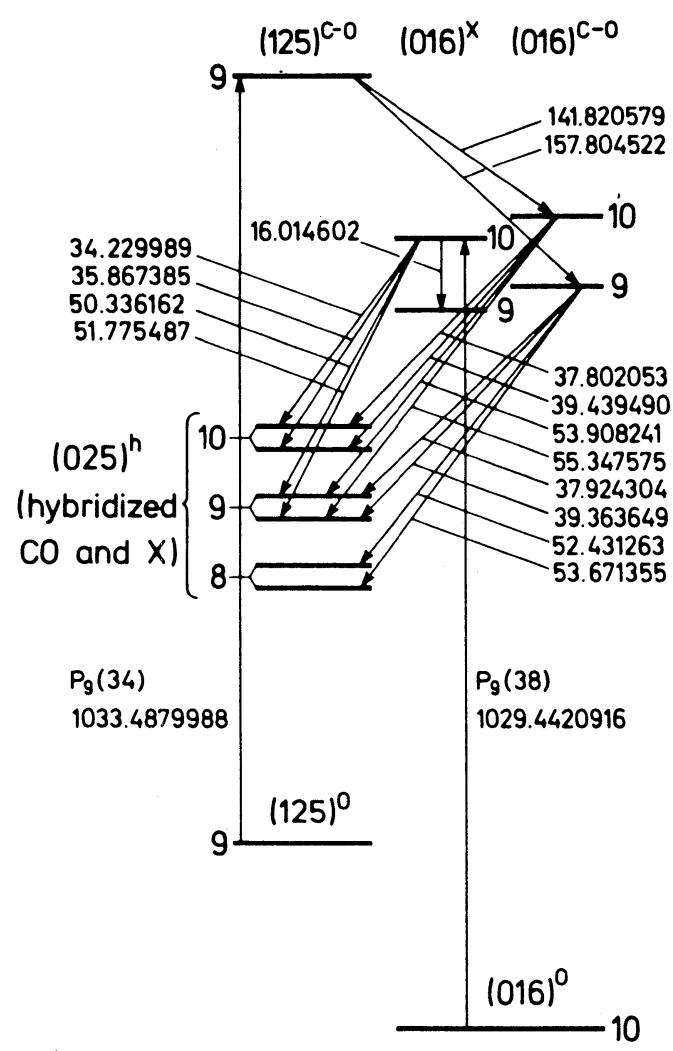

Fig. 9 Energy levels showing interrelations of hybridized and $\mathrm{X}$ states pumped by $9 \mathrm{P}(34)$ and $9 \mathrm{P}(38)$ lines ${ }^{11}$.

どの実験からも確認されている。また $(125)$ 一 (016)のループと (125)－(034) ループのエネ ルギー差は $0.0008 \mathrm{~cm}^{-1}$ であって,このアサ、イ ンメントは間違いないものとされている。

メタノールレーザーの一つの特徵である $90 \mu$ $\mathrm{m}$ 以下の波長の発振は $n$ の遷移による発振であ る予想できる。このような発振は, 絞りをいれ て長波長発振をおさえたり ${ }^{118,119 !}, \mathrm{NaCl}, \mathrm{BaF}_{2}$ などの格子振動反射による出力結合を行ったり して ${ }^{94)}$ ，観測された。その結果みられたこと は, $n=1$ でのエネルギーレベルに対する $E_{\mathrm{co}}$ は $v=1$ の励起レベルに比べて更に $7.4 \mathrm{~cm}^{-1}$ も 低くなることである。このようなことは $n=2$ のレベルに対しても更に顕著にあらわれるもの として注意を要する。 
4.2.3 同位体メタノールのアサインメント $\mathrm{CH}_{3} \mathrm{OD}$ :この分子の赤外吸収スペクトルは 広乵が非常に小さいことがわかっている ${ }^{18)}$ 従って $V=1$ の状態での $V_{3}$ の変化は小さいと考 えられる。 $V=0$ の分子定数に僅かの補正を加 えただけで15本のラインのアサインメンド行わ れた ${ }^{120)}$ 。ごく最近 $\mathrm{CH}_{3} \mathrm{OD}$ の新ラインが見出さ れ，マイクロ波共鳴により一部のアサインメン トが確認されている ${ }^{123)}$ 。

$\mathrm{CD}_{3} \mathrm{OH}$ : 最近半導体レーザーを用いて $\mathrm{P}$, $\mathrm{R}$ ブランチ吸収スペクトルを測定して分子定数 が求められた ${ }^{39)} 。(011)^{\text {co }}$ と (411) のレベルの 間にFermi 共鳴が生じて, (011) のレベルは $\pm 2 \mathrm{~cm}^{-1}$ もシフトすることが求められ, 一部の ラインのアサインメントが可能となった。 6 本 のラインがアサインされている121)。

$\mathrm{CD}_{3} \mathrm{OD}$ : 赤外吸収の $\mathrm{P}, \mathrm{R}$ ブランチが非常に 広がっており， $V_{3}$ が大きく変化していること が予想される。最近の報告で95)，多くの三角型 のレベルが存在することがわかったが，分子定 数の不確かさのために十分な解析は行われてい ない。3 本のラインについてのみ解析が試みら れている ${ }^{1221}$ 。

\section{5. まとめ}

光励起メタノールレーザーの励起光源, 発振 物質, 発振の起源の解析等の現状をのべた。こ れらの結果をもとにして, 新しいラインの発見, 高いエネルギーレベルの振動回転の解析, 分子 定数の決定が行われてきた。効率の良い強力な ラインも見つかっており，遠赤外分光学に応用 されている。レーザーが高安定化するのに伴い， シュタルク効果による解析, 赤外又はマイクロ 波との二重共鳴等も解析に有効な手段を与えた。 アサインメントも行われているが，そのライン は全体の一部にすぎない。吸収とポンプ光との 周波数が偶然に一致する場合に限られているの で, 系統的に調べれば本当に有効な発振が推測 できるであろう。そのためには tunable な光源 が必要であるが, TEA $\mathrm{CO}_{2} レ$ レ゙ーは強い電 界の騒乱によって思った程効果はあがらない。
半導体レーザーも高分解スペクトルがえられる が，我が国では手軽に手に入らない。これらの ものが使えれば偶然の一致からはずれた領域の 解明も可能となるだろう。現在えられている多 すぎるほどの発振ラインも，真に使えそうなも のを系統的に総括することが望まれる。

\section{参考 文 献}

1) J. O. Henningsen: Infrared and Millimeter Waves, Vol. 5 ed. by K. J. Button (Academic Press, 1982) p. 29.

2) M. Inguscio, F. Strumia and J. O. Henningsen: Rev. Infrared and Millimeter Waves, Vol. 2 ed. by K. J. Button, M. Inguscio and F. Strumia (Plenum Press, New York and London, 1983) p. 105.

3) J. C. Petersen and J. O. Henningsen: Rev. Infrared and Millimeter Waves, Vol. 2 ed. by K. J. Button (Plenum Press, 1983) p. 151.

4) S. Kon, T. Kachi, Y. Tsunawaki and M. Yamanaka: Rev. Infrared and Millimeter Waves, Vol. 2 ed. by K. J. Button (1983) p. 159.

5) 網脇, 山中, 近：レーザー研究, 10 (1982) 78.

6) J. O. Henningsen: Molecular Spectroscopy by Far Infrared Laser Emission, ed. H. E. Jorgensen (Kobenhavn, 1984).

7) D. J. E. Knight: Handbook Laser Science and Technology, Vol. 2 Gas Lasers, ed. by M. J. Weber (CRC Press, 1982) p. 459.

8) B. W. Davis, A. Vass, Cr. Pidgeon and G. R. Allan: Opt. Commun. 37 (1981) 303.

9) M. Inguscio, F. Strumia, K. M. Evenson and F. R. Petersen: Int. J. Infrared and Millimeter Waves 5 (1984) 1289

10) J. C. Petersen and G. Duxbury: Appl. Phys. B27 (1982) 19.

11) J. C. Petersen and G. Duxbury: Appl. Phys. B34 (1984) 17.

12) J. O. Henningsen and J. C. Petersen: Infrared Phys. 18 (1978) 475.

13) J. O. Henningsen and J. C. Petersen: J. Mol. Spectrosc. 77 (1979) 298.

14) C. O. Weiss, M. Grinda and K. Siemsen: IEEE J. Quantum Electron. QE-13 (1977) 892.

15) M. S. Feld: 4th Int. Conf. Infrared \& Millimeter Waves, (1979) p. 36.

16) R. B. Gibson: Thesis M.I.T. (1979).

17) H. A. Gebbie, G. Topping, R. Illisley and D. M. Dennison: J. Mol. Spectrosc. 77 (1963) 229.

18) D. R. Woods: Thesis. Univ. Michigan, (1970).

19) A. Borden and E. F. Barker: J. Chem. Phys. 6 (1938) 553. 
20) E. F. Barker and Bosschieter: J. Chem. Phys. 6 (1938) 563.

21) J. S. Koehler and D. M. Dennison: Phys. Rev. 57 (1940) 1006.

22) H. D. Noether: J. Chem. Phys. 10 (1942) 693.

23) D. G. Burkhard and D. M. Dennison: Phys. Rev. 84 (1951) 408.

24) R. H. Hughes, W. E. Good and D. K. Coles: Phys. Rev. 84 (1951) 418.

25) E. V. Ivash and D. M. Dennison: J. Chem. Phys. 21 (1953) 1804.

26) W. J. Thomas, J. T. Cox and W. Gordy: J. Chem. Phys. 21 (1953) 1718.

27) K. T. Hecht and D. M. Dennison: J. Chem. Phys. 26 (1957) 48.

28) D. G. Burkhard and D. M. Dennison: J. Mol. Spectrosc. 3 (1959) 299.

29) R. M. Lees and J. G. Baker: J. Chem. Phys. 48 (1968) 5299.

30) R. M. Lees: J. Chem. Phys. 57 (1972) 2249.

31) R. M. Lees: J. Chem. Phys. 56 (1972) 5887.

32) R. M. Lees: J. Chem. Phys. 57 (1972) 824.

33) Y. Y. Kwan and D. M. Dennison: J. Mol. Spectrosc. 43 (1972) 20.

34) A. Serrallach and H. Gunthard: J. Mol. Spectrosc. 52 (1974) 94.

35) R. G. Lee, R. H. Hunt and E. K. Plyler: J. Mol. Spectrosc. 57 (1975) 138.

36) V. Stern, C. Belorgeot, J. Kachmarsky and K. D. Moller: J. Mol. Spectrosc. 67 (1977) 244.

37) V. Stern, N. Goff, J. Kachmarsky and K. D. Moller: J. Mol. Spectrosc. 79 (1980) 345.

38) W. H. Weber, D. H. Lesile and C. W. Peters: J. Mol. Spectrosc. 89 (1981) 214.

39) W. H. Weber and P. D. Maker: J. Mol. Spectrosc. 93 (1982) 131.

40) G. Herzberg: Infrared and Raman Spectra, (Nostrand Co. Inc. 1945).

41) B. Kirtman: J. Chem. Phys. 37 (1962) 2516.

42) G. Moruzzi and F. Strumia : Infrared Phys. 24 (1984) 257.

43) G. Moruzzi, F. Strumia and F. Colao: Infrared Phys. Phys. 25 (1985) 251.

44) T. Y. Chang and T. J. Bridges: Opt. Commun. 1 (1970) 423.

45) T. Y. Chang: IEEE Trans. Microwave TheoryTech. MTT-22 (1974) 983.

46) C. H. Townes and A. L. Schawlow: Microwave Spectroscopy, (McGraw-Hill, 1955) p. 96.

47) M. Yamanaka, A. Homma, M. Tanaka, Takeda, A. Tanimoto and H. Yoshinaga: Jpn. J. Appl. Phys. 13 (1974) 843.

48) T. Kachi and S. Kon: Infrared Phys. 22 (1982) 337.

49) T. Y. Chang, T. J. Bridges and E. G. Burk: Appl.
Phys. Lett. 17 (1970) 249.

50) H. R. Fetterman, H.R.Schlossberg and J.Waldman : Opt. Commun. 6 (1972) 156.

51) S. F. Dyubko, V. A. Svich and L. D. Fesenko: Sov. J. Tech. Phys. 18 (1974) 1121.

52) D. T. Hodges, R. D. Reel and D. H. Barker: IEEE J. Quantum Electron. QE-9 (1973) 1159.

53) R. J. Wagner, A. J. Zelano and L. H. Ngai: Opt. Commun. 8 (1973) 46.

54) Y. S. Domnin, V. M. Tatarenkov and P. S Shumyatskii : Sov. J. Quant. Electron. 4 (1974) 401.

55) H. E. Radford: IEEE J. Quantum Electron. QE-11 (1975) 213.

56) A. Tanaka, M. Yamanaka and H. Yoshinaga: IEEE J. Quantum Electron. QE-11 (1975) 853.

57) J. Heppner, C. O. Weiss and P. Plainchamp: Opt Commun. 23 (1977) 381.

58) J. O. Henningsen : IEEE J. Quantum Electron. QE14 (1978) 958.

59) G. Bionducci, M. Inguscio, A. Moretti and F. Strumia : Infrared Phys. 19 (1979) 297.

60) M. Inguscio, P. Minguzzi, A. Moretti, F. Strumia and M. Tonelli: Appl. Phys. 18 (1979) 261.

61) H. J. A. Bluyssen, Van Etteger, J. C. Maan and P. Wyder: IEEE J. Quantum Electron. QE-16 (1980) 1347.

62) C. Gastaud, A. Sentz, M. Redon and M. Fourrier: IEEE J. Quantum Electron. QE-16 (1980) 1285.

63) M. Inguscio, A. Moretti and F. Strumia: Opt. Commun. 32 (1980) 87.

64) S. Kon and M. Fukutani: 5th Int. Conf. $I R$ and MM Waves, (1980) 231.

65) B. M. Landsberg: IEEE J. Quantum Electron. QE16 (1980) 704.

66) F. R. Petersen, K. M. Evenson, D. A. Jennings and A. Scalabrin: IEEE J. Quantum Electron. QE-16 (1980) 319.

67) M. Inguscio, N. Ioli, A. Moretti, G. Moruzzi and F. Strumia : Opt. Commun. 37 (1981) 211.

68) M. Inguscio, A. Moretti, G. Moruzzi and F. Strumia : Int. J. Infrared and Millimeter Waves 2 (1981) 953.

69) S. F. Dyubko, L. D. Fesenko, A. S. Shevyryov and V. I. Yartsev: Sov. J. Quant. Electron. 11 (1981) 1248.

70) N. Sokabe, T. Sasabe, T. Kimura, Y. Yasuda and A. Murai: Jpn. J. Appl. Phys. 20 (1981) 2127.

71) B. Hartman and L. Lindgreen: Int. J. Infrared and Millimeter Waves 3 (1982) 503.

72) H. Hirose and S. Kon: Jpn. J. Appl. Phys. 19 (1980) 1131.

73) J. O. Henningsen: Int. J. Infrared and Millimeter Waves 4 (1983) 707.

74) J. O. Henningsen: J. Mol. Spectro. 102 (1983) 399

75) G. Merkle and J. Heppner: Opt. Commun. 51 (1984) 265. 
76) P. Bernard and J. R. Izatt: Int. J. Infrared and Millimeter Waves 4 (1983) 21.

77) N. Ioli, A. Moretti, G. Moruzzi, F. Strumia and F. D. Amato: 9th Int. Conf. Infrared and Millimeter Waves, (1984) p. 459.

78) S. Kon, E. Hagiwara, T. Yano and H. Hirose: Jpn. J. Appl. Phys. 14 (1975) 731.

79) S. Kon, E. Hagiwara, T. Yano and H. Hirose: Jpn. J. Appl. Phys. 14 (1975) 1861.

80) S. F. Dyukko, V. A. Svich and L. D. Fesenko : Radiophys. Quant. Electron. 18 (1975) 1058.

81) B. L. Bean and S. Perkowitz: Optics Letts. 1 (1977) 202.

82) G. Duxbury and H. Herman: J. Phys. B. Atom. Mol. Phys. 11 (1978) 935.

83) M. Grinda and C. D. Weiss: Opt. Commun. 26 (1978) 91.

84) H. Herman and B. E. Preuer: Appl. Phys. 19 (1978) 241.

85) G. Ziegler and U. Durr : IEEE J. QuantumElectron. QE-14 (1978) 708.

86) M. W. Lund and J. A. Davis: IEEE J. Quantum Electron. QE-15 (1979) 537.

87) Y. G. Ni and J. Heppner: Opt. Commun. 32 (1980) 459.

88) A. Scalabrin, F. R. Petersen, K. M. Evenson and D. A. Jennings: Int. J. Infrared and Millimeter Waves 1 (1980) 117.

89) E. C. C. Vasconcellos, A. Scalabrin, F. R. Petersen and K. M. Evenson: Int. Infrared and MM Waves 2 (1981) 533.

70) T. Yoshida, M. Kobayashi, T. Yoshihara, K. Sakai and S. Fujita: Opt. Commun. 40 (1981) 45.

91) A. Vass, R. A. Wood, B. W. Davis and C. R. Pidgeon: Appl. Phys. B27 (1982) 187.

92) T. Yoshida, T. Yoshihara, K. Sakai and S. Fujita: Infrared Phys. 22 (1982) 293.

93) H. Ahmed and J. P. Nicholson: Opt. Commun. 44 (1983) 397.

94) H. Sigg, H. J. A. Bluyssen and P. Wyder: IEEE J. Quantum Electron. QE-20 (1984) 616.

95) D. Pereira, E. D. C. Vasconcellos, A. Scalabrin, K. M. Evenson, F. R. Petersen and D. A. Jennings : Int. J. Infrared and MM Waves 6 (1985) (to be published).

96) F. R. Petersen, K. M. Evenson, D. A. Jennings, J. S. Wells, K. Goto and J. J. Jimenez: IEEE J. Quantum Electron. QE-11 (1975) 838.

97) F. R. Petersen, K. M. Evenson, D. A. Jennings and A. Scalabrin: IEEE J. Quantum Electron. QE-16 (1980) 319 .
98) 田中：光学, 11 (1982) 537.

99) T. G. Blaney and D. J. E. Knight: Opt. Commun. 25 (1978) 176.

100) J. O. Henningsen : IEEE J. Quantum Electron. QE13 (1977) 435.

101) E. J. Danielewicz and P. D. Coleman: IEEE J. Quantum Electron. QE-13 (1977) 485.

102) J. O. Henningsen: J. Mol. Spectr. 83 (1980) 70.

103) J. O. Henningsen: J. Mol. Spectr. 85 (1981) 282.

104) R. M. Lees, M. A. Walton and J. O. Henningsen : J. Mol. Spectr. 88 (1981) 90.

105) J. O. Henningsen : IEEE J. Quantum Electron. QE18 (1982) 313.

106) J. O. Henningsen : J. Mol. Spectr. 91 (1982) 430.

107) J. O. Henningsen, M. Inguscio, A. Morreti and F. Strumia: IEEE J. Quantum Electron. QE-18 (1982) 1004.

108) J. O. Henningsen, M. Inguscio, A. Morreti and F. Strumia : IEEE J. Quantum Electron. QE-18 (1982) 1004.

109) D. J. Bedwell, G. Duxbury, H. Herman and C. A. Drevgo: Infrared Phys. 18 (1978) 453.

110) R. M. Lees, C. Young, J. Linde and B. A. Oliver : J. Mol. Spectr. 75 (1979) 161.

111) J. C. Petersen, D. Igner and G. Duxbury: J. Mol. Spectr. 100 (1983) 396.

112) P. Bernard and J. R. Izatt: Appl. Opt. 22 (1983) 940.

113) F. Strumia and M. Inguscio: Infrared and Millimeter Waves, Vol. 5 ed. by K. J. Button (Academic Press, 1982) p. 129.

114) M. Inguscio, N. Ioli, A. Moretti, F. Strumia and F. DAmato: Int. J. Infrared and MM Waves 5 (1984) 1615.

115) J. P. Sattler, T. L. Worchesky and W. A. Riessler : Infrared Phys. 18 (1978) 521.

116) J. P. Sattler, W. A. Riessler and T. L. Worchesky: Infrared Phys. 19 (1979) 217.

117) R. Forber and M. Feld: 4th Int. Conf. IR and $M M$ Waves, (1979) p. 34.

118) J. O. Henningsen: Int. J. Infrared and MM Waves 4 (1983) 707.

119) J. O. Henningsen: J. Mol. Spectr. 102(1983) 399.

120) T. Kachi, M. Fukutani and S. Kon: Int. J. Infrared and MM Waves 3 (1982) 401.

121) T. Kachi and S. Kon: Int. J. Infrared and MM Waves 4 (1983) 767.

122) 加地：名古屋大学学位論文 (1984).

123) J. C. Petersen and G. Duxbury: Appl. Phys. 37B (1985) 209. 